\title{
Cardiac Myxoma- A case series from a Cardiothoracic Unit in a developing country: Sri Lanka
}

\author{
Muditha N Lansakara" ${ }^{*}$, Mohomad N Jazeel ${ }^{1}$, Athula Wijethunga', Kumaradasan Gnanakanthan', \\ Samath D Dharmaratne ${ }^{2}$ \\ From World Society of Cardiothoracic Surgeons 25th Anniversary Congress, Edinburgh \\ Edinburgh, UK. 19-22 September 2015
}

\section{Background/Introduction}

Myxomas remain the most common benign primary cardiac tumors, where it's growth can masquerade as mitral stenosis, infective endocarditis and collagen vascular disease. This tumour is rare with an estimated incidence of $0.0067 \%-0.33 \%$. They can lead to embolisation, conduction disturbances and lethal valve obstructions.

\section{Aims/Objectives}

To describe socio-demographic characteristics, presentation and outcome of cardiac myxoma patients presenting to our Cardiothoracic Unit.

\section{Method}

All patients who presented and underwent surgical excision at our Cardiothoracic Unit, and histologically proven as cardiac myxoma were included over a period of six years from January 2009. Data were collected from the operation note data base and the patient records and was analyzed by SPSS statistical software.

\section{Results}

There were 31 patients who underwent surgery. Their age ranged from 15 years to 69 years with a mean age of 43.2 years. The majority $(71 \%)$ were females. The main presenting symptoms were shortness of breath $(43.5 \%)$ and stroke (34.8\%). No one died from the surgery and no one suffered significant morbidity. All patients had myxomas in the left atrium where majority were attached to the inter atrial septum (80.5\%) Almost all recovered from strokes without residual effects

Department of Cardiothoracic Surgery, Teaching Hospital, Kandy, Sri Lanka Full list of author information is available at the end of the article

\section{Discussion/Conclusion}

By early diagnosis and prompt surgery, myxoma can be treated with minimal complications with the desired outcome. Sometimes a high degree of suspicion is required for early diagnosis.

\section{Authors' details}

'Department of Cardiothoracic Surgery, Teaching Hospital, Kandy, Sri Lanka. ${ }^{2}$ Department of Community Medicine, Faculty of Medicine, University of Peradeniya, Sri Lanka and Institute for Health Metrics and Evaluation, Department of Global Health, School of Public Health, University of Washington, Seattle, WA, USA.

Published: 16 December 2015

doi:10.1186/1749-8090-10-S1-A285

Cite this article as: Lansakara et al:: Cardiac Myxoma- A case series from a Cardiothoracic Unit in a developing country: Sri Lanka. Journal of Cardiothoracic Surgery 2015 10(Suppl 1):A285.
Submit your next manuscript to BioMed Central and take full advantage of:

- Convenient online submission

- Thorough peer review

- No space constraints or color figure charges

- Immediate publication on acceptance

- Inclusion in PubMed, CAS, Scopus and Google Scholar

- Research which is freely available for redistribution

Submit your manuscript at www.biomedcentral.com/submit
() Biomed Central 